\title{
A normalised seawater strontium isotope curve: possible implications for Neoproterozoic-Cambrian weathering rates and the further oxygenation of the Earth
}

\author{
G. A. Shields \\ Geologisch-Paläontologisches Institut, Westfälische Wilhelms-Universität, Correnstr. 24, 48149 Münster, Germany
}

Received: 9 February 2007 - Published in eEarth Discuss.: 22 March 07

Revised: 15 June 2007 - Accepted: 8 July 2007 - Published: 18 July 2007

\begin{abstract}
The strontium isotope composition of seawater is strongly influenced on geological time scales by changes in the rates of continental weathering relative to ocean crust alteration. However, the potential of the seawater ${ }^{87} \mathrm{Sr} /{ }^{86} \mathrm{Sr}$ curve to trace globally integrated chemical weathering rates has not been fully realised because ocean ${ }^{87} \mathrm{Sr} /{ }^{86} \mathrm{Sr}$ is also influenced by the isotopic evolution of $\mathrm{Sr}$ sources to the ocean. A preliminary attempt is made here to normalise the seawater ${ }^{87} \mathrm{Sr} /{ }^{86} \mathrm{Sr}$ curve to plausible trends in the ${ }^{87} \mathrm{Sr} /{ }^{86} \mathrm{Sr}$ ratios of the three major Sr sources: carbonate dissolution, silicate weathering and submarine hydrothermal exchange. The normalised curve highlights the Neoproterozoic-Phanerozoic transition as a period of exceptionally high continental influence, indicating that this interval was characterised by a transient increase in global weathering rates and/or by the weathering of unusually radiogenic crustal rocks. Close correlation between the normalised ${ }^{87} \mathrm{Sr} /{ }^{86} \mathrm{Sr}$ curve, a published seawater $\delta^{34} \mathrm{~S}$ curve and atmospheric $\mathrm{pCO}_{2}$ models is used here to argue that elevated chemical weathering rates were a major contributing factor to the steep rise in seawater ${ }^{87} \mathrm{Sr} /{ }^{86} \mathrm{Sr}$ from $650 \mathrm{Ma}$ to $500 \mathrm{Ma}$. Elevated weathering rates during the Neoproterozoic-Cambrian interval led to increased nutrient availability, organic burial and to the further oxygenation of Earth's surface environment. Use of normalised seawater ${ }^{87} \mathrm{Sr} /{ }^{86} \mathrm{Sr}$ curves will, it is hoped, help to improve future geochemical models of Earth System dynamics.
\end{abstract}

\section{Introduction}

Strontium in modern seawater $\left({ }^{87} \mathrm{Sr} /{ }^{86} \mathrm{Sr} \sim 0.709\right)$ derives from two major sources: the submarine, chemical alteration of ocean crust $\left({ }^{87} \mathrm{Sr} /{ }^{86} \mathrm{Sr} \sim 0.703\right.$ : Hofmann, 1997) and the subaerial, chemical weathering of the continental crust and

Correspondence to: G. A. Shields

(gshields@uni-muenster.de) its sedimentary cover $\left({ }^{87} \mathrm{Sr} /{ }^{86} \mathrm{Sr} \sim 0.712\right.$ : Palmer and Edmond, 1989; Peucker-Ehrenbrink and Miller, 2006). The ${ }^{87} \mathrm{Sr} /{ }^{86} \mathrm{Sr}$ signatures of these two isotopic end members indicate that about twice as much ocean $\mathrm{Sr}$ derives from river runoff (RR) than from hydrothermal exchange (MI). Because seafloor spreading rates, which determine ocean crust production, have exhibited only limited variation over the past 150 Myr (Rowley, 2002; Cogné and Humler, 2006), attempts have been made to relate the marine carbonate-based seawater ${ }^{87} \mathrm{Sr} /{ }^{86} \mathrm{Sr}$ curve to changes in globally integrated chemical weathering rates only (Francois and Walker, 1992; Kennedy et al., 2006). This approach can be challenged for older time intervals because of the lack of direct constraints on seafloor spreading rates before about $180 \mathrm{Ma}$. Further complications arise from the fact that seawater ${ }^{87} \mathrm{Sr} /{ }^{86} \mathrm{Sr}$ is affected not only by changes in the rates of continental weathering relative to sea-floor spreading but also by variations in the isotopic composition of river runoff and the upper mantle. Uncertainties in the ${ }^{87} \mathrm{Sr} /{ }^{86} \mathrm{Sr}$ of past river runoff, in particular, undermine the potential of the seawater ${ }^{87} \mathrm{Sr} /{ }^{86} \mathrm{Sr}$ curve to be an unambiguous tracer of chemical weathering (Veizer and Mackenzie, 2003). The ${ }^{87} \mathrm{Sr} /{ }^{86} \mathrm{Sr}$ signature of RR can be viewed as a function of the ratio between carbonate and silicate weathering rates with respect to Sr. The chief reasons for this division are that 1) the carbonate component, being primarily of marine authigenic origin, is likely to be far younger and therefore less radiogenic than the silicate component from the same region, whether of igneous, metamorphic or sedimentary origin; 2) carbonate rocks are easily soluble and exceptionally rich in $\mathrm{Sr}$ compared with almost all other rockforming minerals; 3 ) the isotopic composition of the marine carbonate component can easily be estimated once the age distribution of sediments undergoing weathering is known because carbonates should retain to a close approximation the isotopic composition of contemporaneous seawater; and 4) carbonate weathering rates are less susceptible to changes in erosion/denudation rate as carbonate minerals undergo

Published by Copernicus Publications on behalf of the European Geosciences Union. 


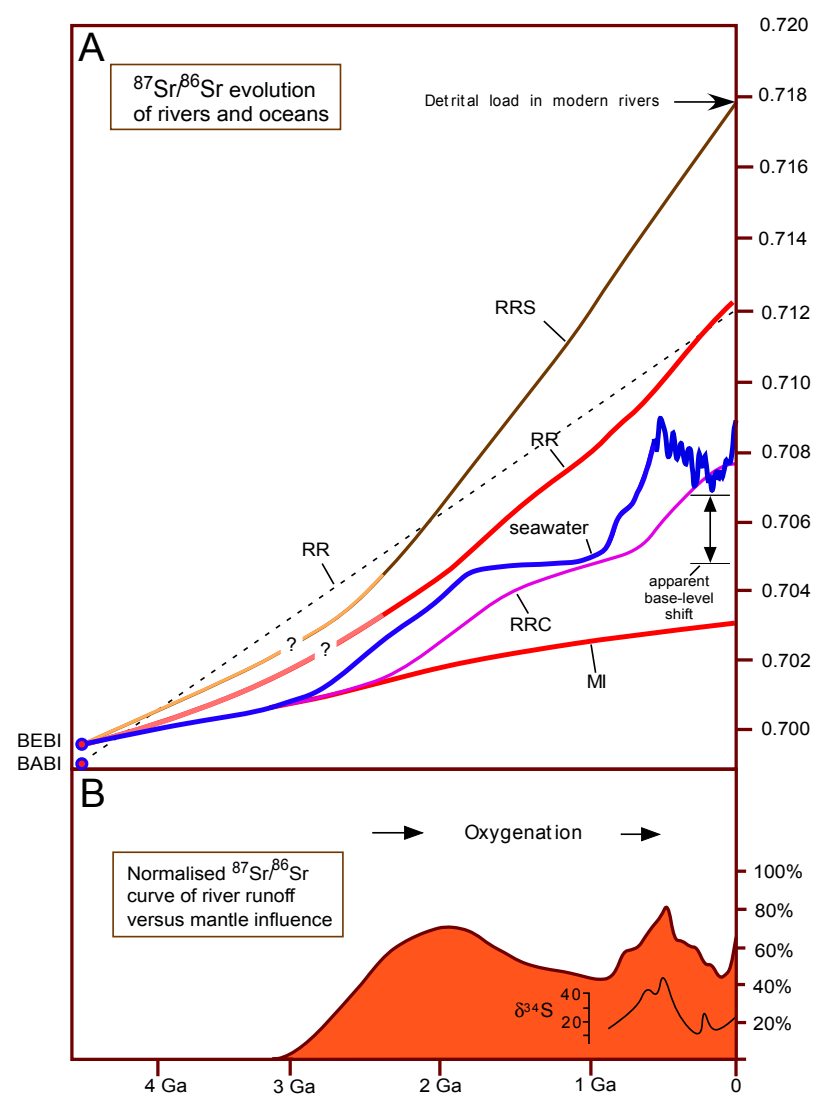

Fig. 1. Sr isotope evolution of seawater and ocean fluxes (A) and its implications for the relative influence of continental weathering on ocean composition (B). The seawater ${ }^{87} \mathrm{Sr} /{ }^{86} \mathrm{Sr}$ curve (Veizer et al., 1999; Shields and Veizer, 2002) in (A) has been constructed from the lowermost ratios for each time interval. The river runoff (RR) curve has been determined by assuming a 9:11 relationship between Sr input from marine carbonate weathering (RRC) and silicate weathering (RRS), respectively. The RRC curve assumes that sediments undergoing weathering have a skewed age distribution, with a mean age of $250 \mathrm{Myr}$ (Peucker-Ehrenbrink and Miller, 2006), and so lags seawater ${ }^{87} \mathrm{Sr} /{ }^{86} \mathrm{Sr}$ by $>250 \mathrm{Myr}$. The RRS curve is an idealistic representation based on predicted crustal evolution (O'Nions et al., 1979); other authors assume much earlier crustal $\mathrm{Rb} / \mathrm{Sr}$ differentiation with minimal isotopic evolution (Kamber and Webb, 2001). Ocean crust alteration provides less radiogenic $\mathrm{Sr}$ to the oceans (MI). The curve in (B) assumes that seawater ${ }^{87} \mathrm{Sr} /{ }^{86} \mathrm{Sr}$ results from simple binary mixing between RR and MI, and shows that the influence of continental weathering was less prior to $2.5 \mathrm{Ga}$, and negligible prior to $3.0 \mathrm{Ga}$. The normalised ${ }^{87} \mathrm{Sr} /{ }^{86} \mathrm{Sr}$ and seawater $\delta^{34} \mathrm{~S}$ curves (Kampschulte and Strauss, 2004; Hough et al., 2006) have been smoothed by plotting values for every 50 million years only.

dissolution below ground as well as at the surface of the Earth (Berner, 2005), thus potentially buffering seawater ${ }^{87} \mathrm{Sr} /{ }^{86} \mathrm{Sr}$ during periods of low erosion rate, such as during the existence of penepained supercontinents.

Although it is widely held that carbonate weathering is the dominant source of $\mathrm{Sr}$ in river runoff (75\%: Brass, 1976; 67\%: Berner and Rye, 1992; 78\%: Veizer and Mackenzie, 2003), variations in the ${ }^{87} \mathrm{Sr} /{ }^{86} \mathrm{Sr}$ ratio of the carbonate component in river runoff have generally not been considered in interpretations of first order seawater ${ }^{87} \mathrm{Sr} /{ }^{86} \mathrm{Sr}$ evolution. Here I propose plausible, but not incontrovertible evolutionary trends for the three major $\mathrm{Sr}$ sources to the ocean: 1) submarine, elemental exchange with ocean crust (MI);2) subaerial, chemical weathering of silicate minerals (RRS); and 3) subaerial dissolution of marine carbonate (and marine sulphate) rocks (RRC), in order to illustrate how the seawater ${ }^{87} \mathrm{Sr} /{ }^{86} \mathrm{Sr}$ curve can be normalised against the isotopic evolution of $\mathrm{Sr}$ sources to the ocean. Because irreversible increases in chemical weathering rates will inevitably raise the baseline of a normalised seawater ${ }^{87} \mathrm{Sr} /{ }^{86} \mathrm{Sr}$ curve, such curves can be used to assess whether evolutionary changes to the terrestrial weathering regime, such as the introduction of a modern soil biota, have resulted in such irreversible changes. Alternatively, an unchanging baseline indicates that globally integrated weathering rates are constrained by other factors, such as $\mathrm{CO}_{2}$-outgassing rates (Walker et al., 1981). The use of more sophisticated, normalised seawater ${ }^{87} \mathrm{Sr} /{ }^{86} \mathrm{Sr}$ curves will it is hoped lead to improved biogeochemical models of the exogenic Earth system.

\section{Evolving ${ }^{87} \mathrm{Sr} /{ }^{86} \mathrm{Sr}$ signatures of $\mathrm{Sr}$ sources to the ocean}

1) Exchange between seawater and ocean crust (MI in Fig. 1) occurs generally at mid-ocean ridges and ridge flanks and supplies $\mathrm{Sr}$ to the ocean that inherits the isotopic composition of its magmatic precursor, the depleted mantle (Spooner, 1976), which is $\sim 0.703$ (Hofmann, 1997). Modern MI represents the accumulation of radiogenic ${ }^{87} \mathrm{Sr}$ in the depleted mantle, which deviated early in Earth history from the bulk earth ${ }^{87} \mathrm{Sr} /{ }^{86} \mathrm{Sr}$ trend as a result of the preferential incorporation of $\mathrm{Rb}$ over $\mathrm{Sr}$ into the crust. This process led to a lessening of the rate of ${ }^{87} \mathrm{Sr} /{ }^{86} \mathrm{Sr}$ increase in MI, either since the onset of modern tectonics close to the Archaean-Proterozoic boundary (O'Nions, 1979) or according to some estimates already by c. $3.8 \mathrm{Ga}$ (McCulloch, 1994).

2) Silicate weathering (RRS in Fig. 1) supplies relatively radiogenic $\mathrm{Sr}$ to the oceans by virtue of the high $\mathrm{Rb} / \mathrm{Sr}$ ratios of most rock-forming silicate minerals and the great mean age of the Upper Continental Crust (UCC). However, it has been noted by several authors that the average isotopic composition of surface rocks exposed to weathering appears to be less radiogenic than would normally be expected simply from the radioactive decay of ${ }^{87} \mathrm{Rb}$, e.g. $\sim 0.716$ (Goldstein and Jacobsen, 1988) instead of the expected value of $>0.730$ (Veizer and Mackenzie, 2003). This has been taken to mean that radiogenic $\mathrm{Sr}$ has been lost preferentially from the silicate pile over time (Goldstein, 1988). The mean ${ }^{87} \mathrm{Sr} /{ }^{86} \mathrm{Sr}$ ratio of the detrital silicate component in modern rivers has 
been estimated to be 0.7178 (Bickle, 1994). This value is consistent with the GLOSS average for subducting sediment of 0.7173 (Plank and Langmuir, 1998) and is accepted here to be the best estimate for the isotopic signature of silicatederived, dissolved $\mathrm{Sr}$ in modern rivers (RRS). Tracing the ${ }^{87} \mathrm{Sr} /{ }^{86} \mathrm{Sr}$ ratio of RRS into the past is difficult because it depends not only on the isotopic evolution of the upper crust but also on the relative susceptibility to weathering, age and $\mathrm{Sr}$ content of the various silicate minerals that make up the exposed parts of the crust.

The $\mathrm{Sr}$ isotopic evolution of crustal silicates would normally be expected to deviate from that of the depleted mantle as a mirror image, albeit with a steeper gradient, taking into account the relative size differences of these two Sr reservoirs (O'Nions et al., 1979). However, there is a tendency for $\mathrm{Rb}$ and $\mathrm{Sr}$ to partition into different mineral phases in the surface environment, which complicates any simplistic trend. $\mathrm{Sr}$ is leached preferentially from silicates during chemical weathering and tends to accumulate conservatively in seawater, whereas $\mathrm{Rb}$, although soluble, has a strong affinity to the clay silicate fractions of both soils and fine-grained marine sediments. Although some current thinking (e.g. Kemp et al., 2006) considers that any such surface effects were more than compensated for by the preferential partitioning of $\mathrm{Rb}$ into granitic melts during partial melting and fractional crystallisation, there is no consensus on the evolution of crustal ${ }^{87} \mathrm{Sr} /{ }^{86} \mathrm{Sr}$ and it is not the aim of this article to contribute to this complex debate. Accordingly, the RRS trend in Fig. 1a is an idealised curve and this should be borne in mind during its interpretation.

3) The dissolution of carbonate rocks (calcite, dolomite) and evaporitic sulphates (gypsum, anhydrite) is considered to be the major source of $\mathrm{Sr}$ to the oceans (Brass, 1976) by virtue of the high $\mathrm{Sr}$ contents and high solubility of those minerals. The isotopic signature of this largely carbonate source today is assumed to be close to that of average Phanerozoic seawater $(\sim 0.708)$ and so changes in the rates and isotopic composition of the carbonate weathering flux (RRC) are widely disregarded in interpretations of ocean ${ }^{87} \mathrm{Sr} /{ }^{86} \mathrm{Sr}$ trends (Veizer and Mackenzie, 2003). However, the ${ }^{87} \mathrm{Sr} /{ }^{86} \mathrm{Sr}$ of RRC is largely dependent on past seawater ${ }^{87} \mathrm{Sr} /{ }^{86} \mathrm{Sr}$ and so will have evolved considerably over time and needs to be considered when interpreting first-order trends in seawater ${ }^{87} \mathrm{Sr} /{ }^{86} \mathrm{Sr}$. According to recent estimates (Peucker-Ehrenbrink and Miller, 2006), about half of all sediments undergoing weathering at the Earth's surface are younger than $0.25 \mathrm{Ga}$, which implies that the rest must be aged between 0.25 and $3.5 \mathrm{Ga}$ with a strong bias towards younger Phanerozoic sedimentary rocks. By assuming that this skewed age distribution has remained the same since carbonate platforms first became commonplace around $2.5 \mathrm{Ga}$, the ${ }^{87} \mathrm{Sr} /{ }^{86} \mathrm{Sr}$ of RRC can be traced back through time (Fig. 1a). Clearly, the changing seawater ${ }^{87} \mathrm{Sr} /{ }^{86} \mathrm{Sr}$ will have exerted considerable control over the isotopic evolution of river runoff independently of the precise age distribution of rocks undergoing weathering or crustal evolution. Significantly, seawater and predicted $\mathrm{RRC}{ }^{87} \mathrm{Sr} /{ }^{86} \mathrm{Sr}$ reached a maximum divergence of $\sim 0.004$ at around $0.5 \mathrm{Ga}$ (Middle Cambrian Early Ordovician) compared with only $\leq 0.001$ since the Permian Period and before the Neoproterozoic.

\section{River runoff versus mantle input through time}

Modern-day river runoff ${ }^{87} \mathrm{Sr} /{ }^{86} \mathrm{Sr}$, at 0.7124 (Palmer and Edmond, 1989; Peucker-Ehrenbrink and Miller, 2006), reflects a mixture of $\mathrm{Sr}$ from the weathering of carbonates $\left({ }^{87} \mathrm{Sr} /{ }^{86} \mathrm{Sr}=0.7077\right)$ and silicates $\left({ }^{87} \mathrm{Sr} /{ }^{86} \mathrm{Sr}=0.7178\right)$. Using these estimates, approximately $55 \%$ of the $\mathrm{Sr}$ in modern rivers derives from the weathering of sedimentary carbonate minerals (cf. 60\%: Bickle, 1994). This appears to be a conservative estimate, being considerably lower than the initially proposed $75 \%$ ratio (Brass, 1976) and also lower than the $67 \%$ ratio used in published models of the exogenic $\mathrm{Sr}$ isotope system (Francois and Walker, 1992; Berner and Rye, 1992). In this regard, it can be argued that the estimated isotopic composition of RRC is only a minimum constraint as marine carbonate and evaporite minerals generally incorporate more radiogenic $\mathrm{Sr}$ during diagenetic alteration. Comparison of the standard Phanerozoic seawater ${ }^{87} \mathrm{Sr} /{ }^{86} \mathrm{Sr}$ curve (Veizer et al., 1999) with earlier attempts based on analyses of bulk carbonate (Burke et al., 1982) suggests that the soluble component of marine carbonates exposed to weathering exhibits on average a ${ }^{87} \mathrm{Sr} /{ }^{86} \mathrm{Sr}$ ratio that is at least 0.0001 higher than contemporaneous seawater. If the ${ }^{87} \mathrm{Sr} /{ }^{86} \mathrm{Sr}$ of modern RRC were at least 0.709 , instead of 0.7077 , this would imply a contribution to river runoff of more than $63 \%$, which is in line with previous estimates above. The isotopic composition of the modern RRS flux is not well constrained. In particular, the assumption that the $\mathrm{Sr}$ isotopic composition of detrital silicates accurately represents that of the dissolved Sr component (Bickle, 1994) may overestimate the ${ }^{87} \mathrm{Sr} /{ }^{86} \mathrm{Sr}$ of RRS due to the generally greater susceptibility to weathering of less radiogenic silicate minerals.

In order to use the seawater ${ }^{87} \mathrm{Sr} /{ }^{86} \mathrm{Sr}$ curve as a measure of changes in river runoff (RR) versus mantle $\mathrm{Sr}$ input (MI), I have first estimated the ${ }^{87} \mathrm{Sr} /{ }^{86} \mathrm{Sr}$ of RR by assuming that the conservatively estimated modern ratio of 55:45 between the carbonate and silicate weathering fluxes has remained unchanged throughout the past $2.5 \mathrm{Ga}$. This assumption appears to be somewhat valid as the resultant curve of river runoff ${ }^{87} \mathrm{Sr} /{ }^{86} \mathrm{Sr}$ (Fig. 1a) does not cross even the highest peaks of the seawater ${ }^{87} \mathrm{Sr} /{ }^{86} \mathrm{Sr}$ trend. Indeed, the relative influence of carbonate weathering on the isotopic composition of river runoff is likely to have been even greater in the geological past. This is because carbonate dissolution was probably favoured in the geological past due to the greater acidity of rainfall caused by higher atmospheric $\mathrm{CO}_{2}$ (Kasting and Siefert, 2004), while the absence of land plants and eukaryotic soil biota meant that silicate weathering efficiency was 
likely depressed during much of the Precambrian relative to today (Lenton and Watson, 2004). The flux of Sr derived from carbonate dissolution seems therefore likely to have dominated over that from silicate weathering for as long as carbonate platforms have been abundant on Earth, i.e. since the early Proterozoic or possibly the late Archean. The relative influence of river runoff versus mantle input (Fig. 1b) can now be estimated by considering seawater ${ }^{87} \mathrm{Sr} /{ }^{86} \mathrm{Sr}$ to be a binary mixture of RR and MI.

The resultant normalised ${ }^{87} \mathrm{Sr} /{ }^{86} \mathrm{Sr}$ curve in Fig. 1b displays some significant deviations from the seawater ${ }^{87} \mathrm{Sr} /{ }^{86} \mathrm{Sr}$ curve from which it was derived, and therefore from most previous estimates of river runoff versus mantle input. Most importantly, there is no longer any evidence for a stepwise change in the ${ }^{87} \mathrm{Sr} /{ }^{86} \mathrm{Sr}$ base-level (Fig. 1a) across the Proterozoic-Phanerozoic transition, which had been interpreted previously to indicate an irreversible shift in chemical weathering rates due to the evolution of soil biota on the continents (Kennedy et al., 2006). This result is not particularly sensitive to the precise age model chosen for carbonate sediments undergoing weathering or to the evolutionary model for the silicate weathering component in rivers. Instead, the shift in base-level noted by those authors is now seen to be a predictable consequence of inevitable increases in the ${ }^{87} \mathrm{Sr} /{ }^{86} \mathrm{Sr}$ compositions of the Phanerozoic carbonate weathering and mantle fluxes. Another feature of note is the relative deflation of the Cenozoic ${ }^{87} \mathrm{Sr} /{ }^{86} \mathrm{Sr}$ peak compared with the previously equivalent Cambrian ${ }^{87} \mathrm{Sr} /{ }^{86} \mathrm{Sr}$ peak. The significance of the Neoproterozoic-Cambrian rise in seawater ${ }^{87} \mathrm{Sr} /{ }^{86} \mathrm{Sr}$ can only be fully appreciated when one considers that the ${ }^{87} \mathrm{Sr} /{ }^{86} \mathrm{Sr}$ compositions of both the MI and the RRC fluxes would have been considerably lower during the Neoproterozoic-Cambrian interval.

To my knowledge, the only other example of a normalised seawater ${ }^{87} \mathrm{Sr} /{ }^{86} \mathrm{Sr}$ curve was published by Jacobsen (1988) and expanded upon in two subsequent studies (Asmerom et al., 1991; Kaufman et al., 1993). These studies all used the sparse marine $\mathrm{Nd}$ isotope record to constrain global averages for both riverine $\varepsilon \mathrm{Nd}$ and riverine $\varepsilon \mathrm{Sr}$, by applying the approximately linear relationship between these latter two parameters today (Goldstein and Jacobsen, 1987). In this way, the ${ }^{87} \mathrm{Sr} /{ }^{86} \mathrm{Sr}$ curve could be 'normalised' against the isotopic evolution of the Bulk Earth as well as riverine input (RR), although the approach appears to have been overlooked in subsequent modelling studies (Berner and Rye, 1992; Francois and Walker, 1992; Berner, 2005).

The curves of global erosion rate ( $\mathrm{Sr}$ flux from the continents to the oceans) obtained by Jacobsen (1988) for the period 700-0 Ma and Asmerom et al. (1991) from 850-0 Ma are quite similar to the curve produced by my normalisation (Fig. 1b). Specifically, their results also showed no evidence for a step-wise jump in erosion rates across the ProterozoicPhanerozoic transition. However, there are some significant differences, too. In similar fashion to Veizer et al. (1983), Asmerom et al. (1991) outline an extraordinarily high hy- drothermal flux at $830 \mathrm{Ma}$ with erosion versus hydrothermal influence as low as $10 \%$ of the modern value. At the other extreme, the Jacobsen (1988) study considers modern erosion rates to be the highest of all time. Both these findings can be explained differently when the changing isotopic composition of carbonate rocks undergoing weathering is also taken into consideration. When the buffering effects of carbonate weathering on seawater ${ }^{87} \mathrm{Sr} /{ }^{86} \mathrm{Sr}$ are considered, the relative hydrothermal influence at $830 \mathrm{Ma}$ is no greater than that during the mid-Paleozoic, while the modern peak in erosion rates appears considerably less pronounced than that during the Cambrian period. This latter finding seems reasonable considering 1) the evidence for colossal mountain building during the Neoproterozoic-Cambrian interval (e.g. Jacobsen, 1988; Squire et al., 2006), 2) the requirement that $\mathrm{CO}_{2}$ drawdown due to $\mathrm{Ca}-\mathrm{Mg}$ silicate weathering match outgassing rates (Walker et al., 1981), which are likely to have been at least as high or higher in the past (Berner, 2005), and 3) the likelihood that modern seawater ${ }^{87} \mathrm{Sr} /{ }^{86} \mathrm{Sr}$ is anomalously high because of the weathering of unusually radiogenic rocks in the Himalayan orogen.

With newer marine $\varepsilon \mathrm{Nd}$ data becoming available (Felitsyn et al., 2002; Wright et al., 2002), it could be argued that the Jacobsen (1988) approach could provide a less idealistic RRS curve than that used in the present study. The major problem with this approach is that more recent estimates of average riverine ${ }^{87} \mathrm{Sr} /{ }^{86} \mathrm{Sr}$ and average marine $\varepsilon \mathrm{Nd}$ no longer fit the linear correlation $(\varepsilon \mathrm{Sr}$ in rivers $=-6.44 \varepsilon \mathrm{Nd}$ in rivers + 31.2) established by Goldstein and Jacobsen (1987). Indeed, the assumption that $\varepsilon \mathrm{Nd}$ in seawater $=\varepsilon \mathrm{Nd}$ in rivers, and is in turn linearly proportional to $\varepsilon \mathrm{Sr}$ in rivers requires that average isotopic composition also averages fluxes, while if any such linear correlation exists its slope is likely to be highly lithology dependent and therefore variable over both space and time. This is best illustrated by the inordinately dominant influence that carbonate weathering exerts on riverine $\varepsilon$ Sr but not on $\varepsilon \mathrm{Nd}$.

\section{A Neoproterozoic-Cambrian weathering event?}

The Neoproterozoic-Cambrian rise in the normalised seawater ${ }^{87} \mathrm{Sr} /{ }^{86} \mathrm{Sr}$ curve can be explained by one or more of three different factors: 1) an increase in the ${ }^{87} \mathrm{Sr} /{ }^{86} \mathrm{Sr}$ ratio of the rocks undergoing weathering, and therefore of continental runoff, above that predicted by the idealised trend (RRS) shown in Fig. 1a; 2) a decrease in the mantle $\mathrm{Sr}$ input and/or seafloor spreading rates; and 3) a reversible increase in overall continental (or merely silicate) weathering rates.

The Neoproterozoic-Cambrian rise in seawater ${ }^{87} \mathrm{Sr} /{ }^{86} \mathrm{Sr}$ could have been caused by changes in the isotopic composition of continental runoff, such that the ${ }^{87} \mathrm{Sr} /{ }^{86} \mathrm{Sr}$ of overall runoff was scarcely different from today's value. However, assuming a modern-like mantle flux but lower MI and RRC ${ }^{87} \mathrm{Sr} /{ }^{86} \mathrm{Sr}$, this would imply that the ${ }^{87} \mathrm{Sr} /{ }^{86} \mathrm{Sr}$ of the silicate 
component must have risen to over 0.722 compared with 0.718 today. Considering the wide range of isotopic compositions exhibited by river runoff today ( 0.703 to 0.77 ), a more radiogenic, globally averaged continental runoff in the geological past is not inconceivable, despite the inevitable effect that radioactive decay has in making rocks more radiogenic with time. Existing data are scarce. Nevertheless, neither the $\mathrm{Nd}$ isotope composition of seawater (Jacobsen, 1988; Felitsyn and Morad, 2002) nor the $\mathrm{Sr}$ isotope compositions of detrital silicates (Goldstein, 1988) are consistent with more radiogenic continental runoff during the late Neoproterozoic and Cambrian relative to today. Initial ${ }^{87} \mathrm{Sr} /{ }^{86} \mathrm{Sr}$ ratios for shales (Goldstein, 1988) are consistently lower than 0.720 throughout the Phanerozoic shale record, and average 0.715 during the Cambrian Period of elevated seawater ${ }^{87} \mathrm{Sr} /{ }^{86} \mathrm{Sr}$, which is consistent with the idealised RRS curve shown in Fig. 1.

The excellent correlation between the normalised seawater ${ }^{87} \mathrm{Sr} /{ }^{86} \mathrm{Sr}$ curve and seawater $\delta^{34} \mathrm{~S}$ (Fig. 1b) implies that absolute fluxes and not the isotopic evolution of those fluxes lead to first-order ${ }^{87} \mathrm{Sr} /{ }^{86} \mathrm{Sr}$ trends. This is because the seawater $\delta^{34} \mathrm{~S}$ record is thought to reflect changes in the biogeochemical cycling of sulphur (Strauss, 1999), and so ought to be independent of changes in the ${ }^{87} \mathrm{Sr} /{ }^{86} \mathrm{Sr}$ isotopic composition or age of rocks exposed to weathering. In this regard, although tectonic upheavals can feasibly change the globally integrated age (Halverson et al., 2007), and therefore ${ }^{87} \mathrm{Sr} /{ }^{86} \mathrm{Sr}$ of rocks undergoing weathering (Goldstein and Jacobsen, 1987), it seems that such changes may only have effected second order variations in the seawater ${ }^{87} \mathrm{Sr} /{ }^{86} \mathrm{Sr}$ curve. This conclusion is consistent with the commonly held interpretation that the Neoproterozoic-Cambrian interval was characterised elevated weathering rates (Derry et al., 1992). Alternatively, a 50\% decrease in the mantle input flux would have been sufficient to cause the Neoproterozoic-Cambrian rise and could potentially also have caused an increase in seawater $\delta^{34} \mathrm{~S}$ (Strauss, 1999). However, such a large, sustained decrease in seafloor spreading rates seems improbable during a period of exceptionally rapid continental reconfiguration, generally high sea-levels and widespread arc collision and rifting (Kirschvink et al., 1997). The most plausible explanation for the Neoproterozoic-Cambrian rise is therefore a sustained increase in overall continental and/or silicate weathering rates.

Times of low continental influence on ocean ${ }^{87} \mathrm{Sr} /{ }^{86} \mathrm{Sr}$ correlate with the existence of the supercontinents Rodinia and Pangaea, while their break-up is associated with sustained increases in continental influence on the ocean $\mathrm{Sr}$ isotope budget. One possible explanation for this connection is that increased rates of physical weathering due to tectonic uplift lead to higher overall chemical weathering rates (Gaillardet et al., 1999) during times of supercontinent break-up and microcontinent collision (Jacobsen and Kaufman, 1999; Squire et al., 2006). In support of this interpretation, the normalised ${ }^{87} \mathrm{Sr} /{ }^{86} \mathrm{Sr}$ curve correlates well with sediment flux rates (Hay et al., 2001). while the rise to peak ${ }^{87} \mathrm{Sr} /{ }^{86} \mathrm{Sr}$ values correlates with the formation of huge mountain chains, such as the Pan-African chains and the "Transgondwanan Supermountain" (Jacobsen, 1988; Squire et al., 2006). Similarly, increases in silicate weathering during the break-up of supercontinents have also been predicted from modelling studies which looked at the effects of reconfiguration on climate and runoff (e.g. Donnadieu et al., 2006). However, sustained increases in silicate weathering rates are only thought to be possible so long as increased $\mathrm{CO}_{2}$ fluxes accompany them (Walker et al., 1981), in which case increased rates of $\mathrm{CO}_{2}$ degassing from carbonate metamorphism (Bickle, 1994) and granitisation during assembly of the supercontinent Gondwana may be relevant. Increases in the efficiency of silicate weathering may also have occurred during the Neoproterozoic-Cambrian interval, caused by the evolution of multicellular soil biota (Kennedy et al., 2006; Lenton and Watson, 2004). However, any such irreversible change in weathering efficiency must have been accompanied by a decline in overall continental weathering rates after the Cambrian Period because normalised baseline ${ }^{87} \mathrm{Sr} /{ }^{86} \mathrm{Sr}$ levels do not appear to change throughout geological time.

It has long been noted that the long-term seawater ${ }^{87} \mathrm{Sr} /{ }^{86} \mathrm{Sr}$ record correlates positively with $\delta^{34} \mathrm{~S}$ during the Phanerozoic (and negatively with $\delta^{13} \mathrm{C}$ ) and this has been taken to indicate a tectonic control on global C- and Sbiogeochemical cycles (Strauss, 1999; Veizer et al., 1999). The normalised ${ }^{87} \mathrm{Sr} /{ }^{86} \mathrm{Sr}$ curve improves the correlation with $\delta^{34} \mathrm{~S}$ and extends it back to c. $800 \mathrm{Ma}$ (Fig. 1b), which implies that increased chemical weathering rates led to higher rates of sulphate reduction (and pyrite burial), presumably linked to higher rates of organic carbon degradation. The alternative proposition that rates of weathering might control seawater $\delta^{34} \mathrm{~S}$ directly by changing the riverine sulphate flux can be excluded as this would lead to an inverse correlation between the two isotopic parameters (Bottrell and Newton, 2006). Correlation between globally integrated organic degradation rates and enhanced chemical weathering rates is consistent with the notion that bioproductivity is limited over geological time scales by the availability of phosphorus (Lenton and Watson, 2000), which can only be derived from the weathering of rocks. The onset of the ${ }^{87} \mathrm{Sr} /{ }^{86} \mathrm{Sr}$ rise also marks the beginning of unusually high $\delta^{13} \mathrm{C}$ values that were set to become characteristic for the later Neoproterozoic. Thus, it could be argued that this sustained, weathering-driven increase in productivity also led to higher rates of organic carbon burial in the newly formed passive margins of the rifting supercontinent, and so presumably was the major driver towards the further oxygenation of the surface environment at this time (Derry et al., 1992). Nevertheless, caution needs to be applied to the interpretation of $\delta^{13} \mathrm{C}$ values directly in terms of organic burial, because they only represent a relative measure of reduced versus carbonate carbon burial rates. In other words, they cannot be interpreted in terms of absolute carbon burial rates, 
which are dictated primarily by $\mathrm{CO}_{2}$-outgassing rates. In this regard, the well characterised trend towards lower average and peak $\delta^{13} \mathrm{C}$ values from the Ediacaran to the Cambrian (e.g. Shields, 1999) is equally consistent with either a decrease or an increase in absolute carbon burial.

Recent studies have emphasised the role of terrestrial biota in increasing both $\mathrm{P}$ weathering rates (Lenton and Watson, 2004) and overall silicate weathering rates (Kennedy et al., 2006) during the Neoproterozoic-Cambrian interval. Although the evolution of terrestrial eukaryotes by $600 \mathrm{Ma}$ (Heckman et al., 2001; Yuan et al., 2005) may be one cause for the increase in weathering rates, their influence was clearly transient as seawater ${ }^{87} \mathrm{Sr} /{ }^{86} \mathrm{Sr}$ decreased steadily after its Late Cambrian peak. This may be due to the establishment of a new equilibrium between more efficient drawdown of atmospheric $\mathrm{CO}_{2}$ by silicate weathering and the endogenic $\mathrm{CO}_{2}$ flux, resulting in generally lower $\mathrm{pCO}_{2}$ during the Phanerozoic eon. A similar scenario has been suggested to take place after the evolution of vascular land plants during the later Palaeozoic, whereby the evolution of land plants is considered to have accelerated weathering (Berner, 2004), leading to eutrophication, $\mathrm{CO}_{2}$ disequilibrium and the contemporaneous Permo-Carboniferous glaciations, as well as higher atmospheric oxygen levels (Lenton, 2001). Similarly, enhanced $\mathrm{CO}_{2}$ sequestration through weathering may have contributed to, and even been an adaptation to low $\mathrm{pCO}_{2}$ during the Cryogenian Period, considering that the last living ancestor of bryophytes and land plants is believed to have lived about 700 Myr ago (Heckman et al., 2001). The subsequent increase in $\mathrm{CO}_{2}$ outgassing during Gondwanan assembly may then, together with the more efficient terrestrial soil ecosystems, have boosted overall chemical weathering rates, ocean productivity and led to the sustained release of free oxygen during the Ediacaran and Cambrian Periods

As mentioned above, increases in globally integrated weathering rates over geological time scales may require concomitant increases in the endogenic $\mathrm{CO}_{2}$ flux.(Berner, 1999). The $\mathrm{pCO}_{2}$ model GEOCARB III (Berner and Kothvala, 2001) shows that the all-time highs in seawater ${ }^{87} \mathrm{Sr} /{ }^{86} \mathrm{Sr}$ coexisted with a Phanerozoic $\mathrm{pCO}_{2}$ acme of as much as $20 \mathrm{PAL}$ or more. Earlier Neoproterozoic $\mathrm{pCO}_{2}$ levels are likely to have been considerably lower during glaciations between c. $730 \mathrm{Ma}$ and $635 \mathrm{Ma}$, bearing in mind that constraints from the marine carbonate record suggest levels lower than 10 PAL by $750 \mathrm{Ma}$ even before the onset of glaciation (Riding, 2006). It seems highly unlikely that such a rise in $\mathrm{pCO}_{2}$ since 635 Ma could have been sustained during widespread orogeny (Squires et al., 2006), especially following the emergence of more efficient $\mathrm{CO}_{2}$-sequestration mechanisms in cyanobacteria and terrestrial biota, if it had not been supported by a higher endogenic $\mathrm{CO}_{2}$ flux through metamorphism and volcanism. These considerations as well as the constancy of the normalised ${ }^{87} \mathrm{Sr} /{ }^{86} \mathrm{Sr}$ baseline argues against any irreversible changes in chemical weathering rates, thus providing strong support for the current paradigm that globally integrated weathering rates are limited by $\mathrm{CO}_{2}-$ outgassing on geological time scales, and not by biological innovations.

This new reading of the seawater ${ }^{87} \mathrm{Sr} /{ }^{86} \mathrm{Sr}$ record suggests that its first order trend records changes in globally integrated chemical weathering rates, while its second order features are more likely to be related to changes in the isotopic composition of source fluxes (e.g. Jones and Jenkyns, 2001). By association, long-term trends in seawater $\delta^{34} \mathrm{~S}$ reflect variations in ocean productivity driven by changes in the riverine nutrient flux. The Neoproterozoic-Cambrian interval stands out as a time when increased chemical weathering rates, and increasingly efficient terrestrial weathering regimes, pushed the Earth System to a new state characterised by higher $\mathrm{O}_{2}$ and lower $\mathrm{CO}_{2}$ and accompanied by the appearance of new forms of animal, plant and fungal life.

\section{Conclusions}

The carbonate dissolution component in river runoff has never been considered in interpretations of first order trends in the seawater ${ }^{87} \mathrm{Sr} /{ }^{86} \mathrm{Sr}$ curve despite the dominance of this component today and the certainty that its isotopic composition must have changed greatly in parallel with seawater ${ }^{87} \mathrm{Sr} /{ }^{86} \mathrm{Sr}$ over Earth history. When predictable trends in this parameter and other factors influencing seawater ${ }^{87} \mathrm{Sr} /{ }^{86} \mathrm{Sr}$ are considered, it appears that the isotopic composition of the carbonate component in river runoff has acted as a baseline for the marine ${ }^{87} \mathrm{Sr} /{ }^{86} \mathrm{Sr}$ curve through time, buffering seawater ${ }^{87} \mathrm{Sr} /{ }^{86} \mathrm{Sr}$ during intervals of low continental weathering rates. The constancy of the normalised ${ }^{87} \mathrm{Sr} /{ }^{86} \mathrm{Sr}$ baseline argues against any irreversible changes in chemical weathering rates, and provides strong support to the current paradigm that globally integrated weathering rates are limited by $\mathrm{CO}_{2}-$ outgassing on geological time scales, and not by biological innovations.

One major feature of the seawater ${ }^{87} \mathrm{Sr} /{ }^{86} \mathrm{Sr}$ record is a uniquely high degree of continental influence during the late Neoproterozoic and Cambrian. This is interpreted here to derive mainly from elevated continental weathering rates related to higher $\mathrm{CO}_{2}$-outgassing during this interval of major orogenesis and metamorphism. High weathering rates may explain the evidence for eutrophication around this time in the form of widespread anoxia, massive phosphorite deposits, black shales and high organic degradation rates (high $\delta^{34} \mathrm{~S}$ ). A sustained increase in chemical weathering rates would have led to increased organic burial and is consistent with the further oxygenation of Earth's exogenic system during this interval.

Edited by: N. T. Arndt 


\section{References}

Asmerom, Y., Jacobsen, S. B., Knoll, A. H., and Swett, K.: Sr isotopic variation of Neoproterozoic seawater: Implications for crust evolution, Geochim. Cosmochim. Acta, 55, 2883-2894, 1991.

Berner, R. A.: A new look at the long-term carbon cycle, GSA Today, 9, 1-6, 1999.

Berner, R. A.: The Phanerozoic carbon cycle. Oxford University Press, 150pp. 2005.

Berner, R. A. and Kothvala, Z.: GEOCARB III: A revised model of atmospheric CO2 over Phanerozoic time, Am. J. Sci. 301, 182204, 2001.

Berner, R. A. and Rye, D. M.: Calculation of the Phanerozoic strontium isotope record of the oceans from a carbon cycle model, Am. J. Sci., 292, 136-148, 1992.

Bickle, M. J.: The role of metamorphic decarbonation reactions in returning strontium to the silicate sediment mass, Nature, 367, 699-704, 1994.

Bottrell, S. H. and Newton, R. J.: Reconstruction of changes in global sulphur cycling from marine sulphate isotopes, Earth Sci. Rev., 75, 59-83, 2006.

Brass, G. W.: The variation of the marine ${ }^{87} \mathrm{Sr} /{ }^{86} \mathrm{Sr}$ ratio during Phanerozonic time: interpretation using a flux model, Geochim. Cosmochim. Acta, 40, 721-730, 1976.

Burke, W. H., Denison, R. E., Heatherington, E. A., Koepnick, R. B., Nelson, H. F., and Otto, J. B. Variation of seawater ${ }^{87} \mathrm{Sr} /{ }^{86} \mathrm{Sr}$ through Phanerozoic time. Geology 10, 516-519 (1982).

Cogné, J.-P. \& Humler, E. Trends and Rhythms in global seafloor generation rate. Geochemistry, Geophysics, Geosystems, 7, Q03011, doi:10.1029/2005GC001148, 2006.

Derry, L. A., Kaufman, A. J., and Jacobsen, S. B.: Sedimentary cycling and environmental change in the Late Proterozoic: Evidence from stable and radiogenic isotopes, Geochim. Cosmochim. Acta, 56, 1317-1329, 1992.

Donnadieu, Y., Goddéris, Y., Pierrehumbert, P., Dromart, G., Fluteau, F., and Jacob, R.: A GEOCLIM simulation of climatic and biogeochemical consequences of Pangea breakup, Geochemistry, Geophysics, Geosystems, 7, Q11019, doi:10.1029/2006GC001278, 2006.

Felitsyn, S. and Morad, S.: REE patterns in latest Neoproterozoicearly Cambrian phosphate concretions and associate organic matter, Chemical Geology, 187, 257-265, 2002.

Francois, L. M. and Walker, J. C. G.: Modelling the Phanerozoic carbon cycle and climate: constraints from the ${ }^{87} \mathrm{Sr} /{ }^{86} \mathrm{Sr}$ isotopic ratio of seawater, Am. J. Sci., 292, 81-135, 1992.

Gaillardet, S. J., Dupré, B., Louvat, P., and Allègre, C.: Global silicate weathering and $\mathrm{CO}_{2}$ consumption rates deduced from the chemistry of large rivers, Chemical Geology, 159, 3-30, 1999.

Goldstein, S. J. and Jacobsen, S. B.: The Nd and Sr isotopic systematics of river water dissolved material: Implications for the sources of $\mathrm{Nd}$ and $\mathrm{Sr}$ in seawater. Chemical Geology (Isotope Geoscience section) 66, 245-272, 1987.

Goldstein, S. J. and Jacobsen, S. B.: Nd and Sr isotopic systematics of river water suspended material: Implications for crustal evolution, Earth Planet. Sci. Lett., 87, 249-265, 1988.

Goldstein, S. L.: Decoupled evolution of $\mathrm{Sr}$ and $\mathrm{Nd}$ isotopes in the continental crust and mantle, Nature, 336, 733-738, 1988.

Halverson, G., Dudas, F. Ö., A. C. Maloof, and Bowring, S. A.: Evolution of the ${ }^{87} \mathrm{Sr} /{ }^{86} \mathrm{Sr}$ composition of Neo- proterozoic seawater, Palaeogeog. Palaeoclimat., Palaeoecol., doi:10.1016/j.palaeo.2007.02.028, 2007.

Hay, W. W., Wold, C. N., Söding, E., and Flögel, S.: Evolution of sedimentary fluxes and ocean salinity, in: Geologic modelling and simulation: sedimentary systems, edited by: Merriam, D. F. and Davis, J. C., Kluwer Academic/Plenum Publishers, New York, 153-167, 2001.

Heckman, D. S., Geiser, D. M., Eidell, B. R., et al. Molecular evidence for the early colonization of land by plants and fungi, Science, 291, 1129-1133, 2001.

Hofmann, A. W.: Mantle geochemistry: the message from ocean volcanism, Nature, 385, 219-229, 1997.

Hough, M. L., Shields, G. A., Evins, L. Z., Strauss, H., Henderson, R. A., and Mackenzie, S.: A major sulphur isotope at c. 510 Ma: a possible connection anoxia-extinction-volcanism connection during the Early-Middle Cambrian transition?, Terra Nova, 18, 257-263, 2006.

Jacobsen, S. B.: Isotopic constraints on crustal growth and recycling, Earth Planet. Sci. Lett., 90, 315-329, 1988.

Jacobsen, S. B. and Kaufman, A. J.: The Sr, C and O isotopic evolution of Neoproterozoic seawater, Chem. Geol., 161, 37-57, 1999.

Jones, C. E. and Jenkyns, H. C.: Seawater Strontium Isotopes, Oceanic Anoxic Events, and Seafloor Hydrothermal Activity in the Jurassic and Cretaceous, Am. J. Sci., 312, 112-149, 2001.

Kamber, B. A. and Webb, G. M.: The geochemistry of late Archaean microbial carbonate: Implications for ocean chemistry and continental erosion history, Geochim. Cosmochim. Acta, 65, 2509-2525, 2001.

Kampschulte, A. and Strauss, H.: The sulfur isotopic evolution of Phanerozoic seawater based on analysis of structurally substituted sulfate in carbonates, Chem. Geol., 204, 255-286, 2004.

Kasting, J. F. and Siefert, J. L.: Life and the evolution of Earth's atmosphere, Science, 296, 1066-1068, 2004.

Kaufman, A. J., Jacobsen, S. B., and Knoll, A. H.: The Vendian record of $\mathrm{Sr}$ and $\mathrm{C}$ isotopic variations in seawater: Implications for tectonics and paleoclimate, Earth Planet. Sci. Lett., 120, 409430, 1993.

Kemp, A. I. S., Hawkesworth, C. J., Paterson, B. A., and Kinny, P.: Episodic growth of the Gondwana Supercontinent from hafnium and oxygen isotopes in zircon, Nature, 439, 580-583, 2006.

Kennedy, M., Droser, M., Meyer, L. M., Pevear, D., and Mrofka, D.: Late Precambrian oxygenation: inception of the clay mineral factory, Science, 311, 1446-1449, 2006.

Kirschvink, J. L., Ripperdan, R. L., and Evans, D. A. D.: Evidence for a large-scale reorganization of Early Cambrian continental masses by inertial interchange true polar wander, Science, 277 , 541-545, 1997.

Lenton, T. M.: The role of land plants, phosphorus weathering and fire in the rise and regulation of atmospheric oxygen, Global Change Biol., 7, 613-629, 2001.

Lenton, T. M. and Watson, A. J.: Redfield revisited 1: Regulation of nitrate, phosphate and oxygen in the ocean, Global Biogeochem. Cycles, 14, 225-248, 2000.

Lenton, T. M. and Watson, A. J.: Biotic enhancement of weathering, atmospheric oxygen and carbon dioxide in the Neoproterozoic, Geophys. Res. Lett., 31, L05202, doi:10.1029/2003GL018802, 2004.

McCulloch, M. T.: Primitive ${ }^{87} \mathrm{Sr} /{ }^{86} \mathrm{Sr}$ from and Archean barite and conjecture on the Earth's age and origin, Earth Planet. Sci. Lett., 
126, 1-13, 1994.

O’Nions, R. K., Evenson, N. M., and Hamilton, P. J.: Geochemical modelling of mantle differentiation and crustal growth, J. Geophys. Res., 84, 6091-6101, 1979.

Peucker-Ehrenbrink, B. and Miller, M. W.: Marine ${ }^{87} \mathrm{Sr} /{ }^{86} \mathrm{Sr}$ record mirrors the evolving upper continental crust, Geochim. Cosmochim Acta, 70, 18, A487, 2006.

Palmer, M. R. and Edmond, J. M.: Strontium isotope budget of the modern ocean, Earth Planet. Sci. Lett., 92, 11-26, 1989.

Plank, T. and Langmuir, C. H.: The chemical composition of subducting sediment and its consequences for the crust and mantle, Chemical Geology, 145, 325-394, 1998.

Riding, R.: Cyanobacterial calcification, carbon dioxide concentrating mechanisms, and Proterozoic-Cambrian changes in atmospheric composition, Geobiology, 4, 299-316, 2006.

Rowley, D.: Rate of plate creation and destruction, Geol. Soc. Am. Bull., 114, 927-933, 2002.

Shields, G. A., Stille, P., and Brasier, M. D.: Isotopic records across two phosphorite giant episodes compared: the PrecambrianCambrian and the late Cretaceous-recent, in: Marine authigenesis: From Global to Microbial, edited by: Glenn, C., PrévôtLucas, L., and Lucas, J., SEPM special volume 66, 103-116, 2000.

Shields, G. A. and Veizer J.: Precambrian marine carbonate isotope database: Version 1.1., Geochemistry, Geophysics, Geosystems, 6, 1-12, 2002.

Spooner, E. T. C.: The strontium isotopic composition of seawater, and seawater-oceanic crust interaction, Earth Planet. Sci. Lett., 31, 167-174, 1976.
Squire, R. J., Campbell, I. H., Allen, C. M., and Wilson, C. J. L.: Did the Transgondwanan Supermountain trigger the explosive radiation of animals on Earth?, Earth Planet. Sci. Lett., 250, 116-133, 2006.

Strauss, H.: Geological evolution from isotope proxy signals - sulphur, Chem. Geol., 161, 89-101, 1999.

Veizer, J. and Mackenzie, F. T.: Evolution of sedimentary rocks, in: Treatise on geochemistry, edited by: F. T., Volume 7, Sediments, diagenesis, and sedimentary rocks, 369-407, 2003.

Veizer, J., Compston, W., Clauer, N., and Schidlowski, M.: ${ }^{87} \mathrm{Sr} /{ }^{86} \mathrm{Sr}$ in late Proterozoic carbonates: Evidence of a "mantle" event at 900 Ma ago., Geochim. Cosmochim. Acta, 47, 292-302, 1983.

Veizer, J., Geiser, D. M., Eidell, B. R., et al.: ${ }^{87} \mathrm{Sr} /{ }^{86} \mathrm{Sr}, \delta^{13} \mathrm{C}$ and $\delta^{18} \mathrm{O}$ evolution of Phanerozoic seawater, Chem. Geol., 161, 59$88,1999$.

Walker, J. C. G, Hays, P. B., and Kasting, J. F.: A negative feedback mechanism for the long-term stabilization of Earth's surface temperature, J. Geophys. Res., 86, 9776-9782, 1981.

Wright, C. A., Barnes, C. R., and Jacobsen, S. B.: Neodymium isotopic composition of Ordovician conodonts as a seawater proxy: Testing paleogeography, Geochem. Geophys. Geosyst., 3(2), 1016, doi:10.1029/2001GC000195, 2002.

Yuan, X., Xiao, S., and Taylor, T. N.: Lichen-like symbiosis 600 million years ago, Science, 308, 1017-1020, 2005. 